\title{
The Vanishing Mediator and Linguistic Hospitality
}

Angelo Bottone

I $\mathrm{n} W$ e, the People of Europe? Balibar argues for a Europe as the interpreter of the world, a 'vanishing mediator' translating languages and cultures. Ricoeur in his last works has considered translation as a paradigm of the attitude towards the other, holding the view that the ethical purposes relating to linguistic hospitality are the model for any kind of hospitality. I intend to contrast Balibar's vanishing mediator with Ricoeur's concept of linguistic hospitality.

In spite of the fact that Étienne Balibar and Paul Ricoeur practically ignore each other in their works, I found some striking similarities in their thoughts regarding the role of languages and translation in Europe. In my paper, I will highlight these common views, with the intention of also showing their differences.

Étienne Balibar published in English in 2004 a collection of essays written during the previous decade, with the title: $W e$, the People of Europe? Reflections on Transnational Citizenship, where he discusses the possibility of giving a concrete meaning to the idea of a European citizenship and thus, of giving content to the project of a democratic Europe. Although the book is mainly focused on political theory, a reflection on translation and the role of languages in the construction of the citizenship in Europe is treated, particularly in two of the essays: Difficult Europe: Democracy under Construction and Europe: Vanishing mediator? In the first of these two essays Difficult Europe: Democracy under Construction, he enumerates four 'worksites of and for democracy', i.e. places where democracy is under construction.

These sites constitute, in my view, domains of initiative and reflection with a view toward a new citizenship in Europe, in the sense of an intellectual matter that needs to be worked in order to give body to a true 'European public space.'1

They are: justice (the building of a juridical order more advanced than national states), reorganization of 'labour time' (the convergence of trade

\footnotetext{
${ }^{1}$ Étienne Balibar, We, the People of Europe? Reflections on Transnational Citizenship? (Princeton: Princeton University Press, 2004), 156-157.
}

(c) 2010 Angelo Bottone http://www.kritike.org/journal/issue 8/bottone december2010.pdf ISSN 1908-7330 
union struggles and the associative movements around projects to reorganize 'labour time' on the European scale), democratisation of borders (the negotiation of the movements of circulation and migration of populations on the planet, in order to carve out a universal right of circulation and residency, including reciprocity of cultural contributions and contacts between civilizations) and culture.

Culture, and above all language, is a worksite of and for democracy insofar it is not merely an instrument of communication, but a trans-individual 'bond' that produces its own forms of identification and counter-identification.

Balibar addresses a well-known and debated question: Which is the language for Europe? It cannot be English because English is more than just a European language but, at the same time, it is less, as it is spoken by the majority and it is 'threatened with breaking up into several relatively separate idioms'. Balibar maintains that the only credible answer will be found not in a code but a practice, better, in 'a constantly transformed system of crossed usages', which is translation. ${ }^{2}$ In an endnote to the text he clarifies that

...the 'community of translation' is also not that in which everyone speaks or understands everyone's else language, but, on the contrary, that in which the role of the 'interpreter', depending on the situations and configurations of exchange, is capable of falling on anyone in turn, passing from the 'majority' to the 'minority' position. ${ }^{3}$

I find it particularly interesting that in this essay translation is defined as the "concrete metalanguage made up of all the equivalence and all the attempts to overcome the 'untranslatable' between idioms". So, the language of Europe will be not an idiom but a meta-language, a social practice that builds a European public opinion and, consequently, democracy. From a sociolinguistic point of view, Balibar notes, the major performers of this praxis are intellectuals and migrant workers, at the opposite sides of society.

In the very last pages of his book, in the essay Europe: Vanishing mediator?, Balibar discusses again issues concerning languages and translation, but on a more symbolic level. He argues for a Europe as the interpreter of the world, translating languages and cultures in different directions. Its role is that of a 'vanishing mediator', a dialectical figure that permits the passage from old to new, a transitory institution or community that creates the conditions for a new society and a new civilisation pattern. In this essay Balibar is answering an appeal from American intellectuals, asking European intellectuals to act as a counterweight to the current US Government's ideology and political power, or as a mediator between subjects involved in current conflicts. Balibar proposes a paradoxical 'antistrategy': Europe is presented not as a

\footnotetext{
2 See Ibid., 177-178.

${ }^{3}$ Ibid., 272.
} 
counterweight, as one could expect, to the US hegemony. He believes that "We must displace the call, we must call in return upon the Americans to think in different terms, we must question the very presuppositions of the demand". ${ }^{4}$ Rather, he proposes this ambiguous figure of the 'vanishing mediator' that creates "the conditions for its own suppression and withering away" 5 but, without which, no transition from old to new would have been possible. This is what Europe should be. Europe, he recognizes, is not capable to influence and mediate conflicts and historical processes but it can "use its own fragilities, and indeterminacies, its own 'transitory' character, as an effective mediation in a process that might bring about a new political culture. ... Or perhaps, even more paradoxically, $[\ldots]$ offer itself as an instrument that other forces in the world, aiming to a transformation of politics, could use and expand to cope with the crisis."'

I am not interested here in considering the particular case of how to contrast the US hegemony but, rather, in the analysis of how Balibar conceives translation and the role of intellectuals in Europe. Even if the concept of a vanishing mediator is not further clarified, Balibar associates it to the role of translators. Europe, he holds, is not the only region in the world where translations are made but, due to its specific history, "nowhere -not even in India or China- was it necessary to organize to the same degree the political and pedagogical conditions of language exchanges". ${ }^{7}$ Balibar believes that this old institutional practice of translation in Europe can be expanded in two directions: firstly, by including new elements in the group of languages taught and practised, and secondly, "by stretching the idea of 'translation' from the merely linguistic to the broader cultural level". 8 Moreover, the idea of the vanishing mediator is a way to restore the political function of the 'organic' intellectuals (organic in the Gramscian sense). "They would continuously broaden the horizon of their translating capacities. ... Intellectuals would 'disappear into their intervention', as Luis Althusser used to say. They would be necessary, but without monopoly. They would be border lines themselves."

Paul Ricoeur, in the last years of his life, specifically dealt with the question of translation in some discourses and short articles that were collected and published in 2006. For many years his only lecture available in English on this topic was Reflections on a new ethos for Europe, written in 1992, where he also addresses the question of languages in Europe.

Ricoeur treats the same problem as Balibar: how to get beyond the nation-state and respond to a political situation without precedents. Ricoeur proposes to formulate the challenge in terms of what he calls 'political imagination'. The necessary transfers of sovereignty in support of a rather new entity, the European Union, cannot be successful on the institutional level

\footnotetext{
${ }^{4}$ Ibid., 233.

5 Ibid.

${ }^{6}$ Ibid., 234.

${ }^{7}$ Ibid.

8 Ibid.

${ }^{9}$ Ibid., 235.
} 
without the changes in attitudes of the ethos of individuals, groups and peoples. He offers three models of what he calls integration of identity and alterity'. Firstly, Ricoeur maintains that the plurality of European languages is a sign of the pluralities of histories, cultures, and traditions in the continent. The only possible form of European cultural citizenship is therefore not a unique language, which would hardly be accepted by all peoples, but the practice of translation that respects differences and identities recognizing their value. This is the first model of integration and he seems to be in complete agreement with Balibar. "Europe is and will remain ineluctably polyglot", Ricoeur maintains, pluralism is "indefinitely desirable to protect" 10

The theoretical pattern of the dialectic between identity and alterity that he applies at numerous levels, I propose to call the 'unity mediated by plurality'. It is worth recalling that in his masterpiece Oneself as Another 11 , Ricoeur considers the 'other' to be not only any other human being, but all possible forms of alterity that the self meets: its own body, its conscience. Language can be added to these possible forms, and translating becomes an experience of alterity as in translation we experience the 'other' in foreign languages but also in the problems we find when using our own language. Common difficulties which are met in translation arise not only from the fact that we speak different languages but from the fact that we speak a language. It is the language itself that implies ambiguity, misunderstanding, inexpressibility, concealment, falsity. The 'other' is already in ourselves. There is no perfect translation because there is no perfect language and even if we were all speaking the same language, we would still have the same difficulties.

These reflections on 'the other in oneself allow Ricoeur to exalt plurality. He claims that language (le language) exists nowhere else than in languages (des langues), analogously humanity exists nowhere else than in many cultures, but there is only one human race thanks to the fact that transferences of meaning, even if difficult, are possible from one language to another. Translatability is a universal principle, an a priori of communication. Translation becomes therefore, the ground for a communal coexistence and, in this particular case, a model for a European citizenship. This implies, for Ricoeur, on the institutional level, the promotion of the study of the living European languages, while on the more broad spiritual level, the extension of the spirit of translation to the relationship between the cultures themselves.

The other two models, which I will mention briefly, are the model of exchange of memories and the model of forgiveness. An integration of identity and alterity presupposes an exchange of narrations, where different subjectivities are involved. Our European history is constituted through divergent, often opposed public accounts of the same cruel events. If the

${ }^{10}$ Richard Kearney ed., Paul Ricoeur The Hermeneutics of Action, (London: SAGE, 1996), 317-355.

11 Paul Ricoeur, Oneself as another (Chicago, The University of Chicago Press, 1992), 
identity of a group is not fixed but built through narration, as Ricoeur maintains, to practice at the cultural level the gesture of hospitality that characterises the work of translators, means to put ourselves into listening to other peoples' customs, fundamental beliefs, deepest convictions and try to express them in our own language. In other words, to translate their stories and our stories. Ricoeur defines this gesture as 'narrative hospitality'. Strongly related to the exchange of memories is the need for forgiveness, a forgiveness without forgetting without which no mutual understanding is possible.

I will focus on the first one of these three models. The original French title of Ricoeur's essay was in a questioning form: Quel éthos nouveau pour l'Europe? Which new ethos for Europe? He answers: "We could speak of a translation ethos whose goal would be to repeat at the cultural and spiritual level the gesture of linguistic hospitality" 12 . This is the first, brief concurrence of the concept of linguistic hospitality, a concept that he developed in his later writings. In his lecture Défi et bonbeur de la traduction, linguistic hospitality is regarded as the pleasure of dwelling within the language of the other and, conversely, the pleasure of hosting the word of the foreigner in one's own house. ${ }^{13}$ "It is really the matter of living with the other in order to take that other to one's home as a guest." 14 . Ricoeur in his last works has considered translation as a paradigm of the attitude towards the other, holding the view that the ethical purposes relating to linguistic hospitality are the model for any kind of hospitality ${ }^{15}$. For example, writing on the ecumenical dialogue between Christian churches, he proposes to consider different religious confessions as foreign languages that need to be studied in order to translate them from inside.

Despite the remarkable convergence of views, the different outcomes of Balibar's vanishing mediator and Ricoeur's linguistic hospitality have to be clarified. I will try to provoke a dialect interchange between these two key concepts.

The 'vanishing mediator' mentioned by Balibar, is a concept elaborated by Fredric Jameson in his essay on Max Weber as a storyteller ${ }^{16}$. It is defined as "a catalytic agent that permits an exchange of energies between two otherwise mutually exclusive terms". ${ }^{17}$ Its essential function is the mediation of changes. So far, we could say that Balibar and Ricoeur agree on the relevant role of languages in the elaboration and the exercise of citizenship: we are not citizens,

\footnotetext{
12 Kearney, op. cit., 5.

13 Paul Ricoeur, On translation (London and New York: Routledge, 2006), 10

14 Kearney, op. cit., 5.

15 Ricoeur, On translation, 23

16 See Fredrick Jameson, The Ideologies of Theory Volume 2: The Syntax of History (London: Routledge, 1988), 3-34.

17 Jameson in this essay maintains that Protestantism assumes in Weber the function of a vanishing mediator because once it "has accomplished the task of allowing a rationalization of innerworldly life to take place, it has no further reason for being and disappears from the historical scene" See Jameson, op. cit., 25 See also Slavoj Žižek and John Millbank The Monstrosity of Christ: Paradox or Dialectic? (Boston: The MIT Press, 2009), 38 where Žižek presents Christ as the vanishing mediator.
} 
but we can become citizens and the practice of translation, taken in its broadest sense, functions as mediation in the processes of creation of citizenship. The point of divergence between Ricoeur and Balibar, if my understanding is correct, lies in the vanishing characteristic of this mediator. It seems to me that Balibar provides no enough support and clarification to the idea that at a certain moment the mediator has no further reason for being and therefore it disappears from the historical scene. Let's consider his examples: Why should Europe create the conditions for its own suppression and withering away? Only because is not able to react from a political point of view to the American initiative? Why should the European intellectuals disappear in their intervention?

Is it true that, as Balibar says, "without this 'vanishing' mediation no transition from the old to the new fabric of society would have been possible"?18 I find in Balibar a nihilistic element that eventually destabilizes his proposal. In order to definitively overcome the state-nation and avoid any temptation to build a European citizenship grounded on forms of ethnicity, he tries to elaborate an anti-identity strategy, where the only goal of the mediator, be this mediator the intellectuals or Europe itself, is to let the others talk. Once this has happened, this mediator's work has been completed. But this is not the case of translators! He clearly holds a distorted view of the work of translator.

As Ricoeur has taught us, even when mediating, the subjectivity of the translator is present and active. His or her identity is not necessarily a negative element if it is open to host, if it is inspired by linguistic hospitality. On the other hand, there could be no subjectivity, and therefore no mediation, without identity. To transport these thoughts in our discussion, we can state that Europe does not come from nothing, so why should it become nothing? Why should Europe vanish? No act of self-sacrifice is necessary to let the other come into being. If we conceive of Europe as an interpreter, it should be a mediator of differences rather than a vanishing one, it should listen to the others and tell their stories in its own words, inside and outside herself. I believe we should talk not of a vanishing mediation but a renewing one and, on this respect, Ricoeur once again enlightens us with his conception of 'tradition', a tradition that goes beyond clichés and anathemas.

I wish to finish with his own words:

It is necessary for us to have gone through the ethical requirement of translation - what I call linguistic hospitality - and through the requirements of the exchange of memories - narrative hospitality- in order to approach the phenomenon of tradition in its specifically dialectical dimension. Tradition means transmission, transmission of things said, of beliefs professed, of norms accepted, etc. Now such a transmission is a living one only if tradition continues to form a partnership with

${ }^{18}$ Balibar, op. cit., 223. 
innovation. Transmission represents the aspect of debt which concerns the past and reminds us that nothing comes from nothing. A tradition remains living, however, only if it continues to be held in an unbroken process of reinterpretation. It is at this point that the reappraisal of narratives of the past and the plural reading of founding events come into effects. ${ }^{19}$

School of Arts, Dublin Business School, Ireland

\section{References}

Balibar, É., We, the People of Europe? Reflections on Transnational Citizenship? (Princeton, Princeton University Press, 2004).

Bottone, A., "Translation as an Ethical Paradigm in the Work of Paul Ricoeur," in S. Kelly and D. Johnston eds., Betwixt and Between: place and cultural translation (Cambridge, Cambridge Scholar Press, 2006). "The Ethical Task of the Translator in Paul Ricoeur," in Paschalis Nikolau and Maria-Venetia Kyritsi eds., Translating Selves: Experience and Identity between Languages and Literatures (London and New York, Continuum Books, 2008).

Eco, U., The Search for the Perfect Language, Oxford, Blackwell, 1997.

Jameson, F., The Ideologies of Theory Volume 2: The Syntax of History (London, Routledge, 1988).

Kearney R. ed., Paul Ricoeur The Hermeneutics of Action (London, SAGE, 1996).

Read J., "Writing in the Conjuncture." in Borderlands 1 (3). Online document at URL < http://www.borderlands.net.au/vol3no1_2004/ read_balibar.htm $>$ Accessed 19.12.2010.

Ricoeur, P., "Quel éthos nouveau pour l'Europe?” in Koslowski P., (ed.) Imaginer l'Europe. Le marché intérieur européen, tâche culturelle et économique, Paris, Cerf. 1992).

, Oneself as another (Chicago, The University of Chicago Press,

"Défi et bonheur de la traduction," a lecture given on the occasion of conferring of the Prix de Traduction pour la promotion des relations franco-allemandes, to the Institut Historique Allemand of Paris, on 15 April 1997.

"Le paradigme de la traduction," an opening lecture given to the Faculté de Théologie protestante de Paris, October 1998, later published in Esprit 253, 8-19.

"Du Concile de Trente au Colloque de Trente," a lecture given at the conference Lutero e i linguaggi dell'Occidente, Trento, 29-31 May 2000.

, La traduzione Una sfida etica (Brescia, Morcelliana, 2002).

${ }^{19}$ R. Kearney ed., op. cit., 8. 
, Sur la traduction (Paris, Bayard, 2004).

, On translation (London and New York, Routledge, 2006).

Žižek, S. and Millbank J., The Monstrosity of Christ: Paradox or Dialectic? (Boston, The MIT Press, 2009). 